\title{
Classroom Interaction Features in EFL: What happens if Obstruction is More Excessive than Construction?
}

\author{
Binti Aisiah Daning Sumari \\ Graduate School \\ Yogyakarta State University \\ Yogyakarta, Indonesia \\ binti.aisiah2016@student.uny.ac.id
}

\author{
Teguh Setiawan \\ Graduate School \\ Yogyakarta State University \\ Yogyakarta, Indonesia
}

\begin{abstract}
This study established qualitative design in attempt to reveal impact exceed of obstruction features than construction which occurred in EFL classroom in Indonesia. This present study involved an English teacher and thirty five students. She taught three times lesson meeting, each of lesson carried out ninety minutes. From the present study found obstruction i.e., short wait time, teacher control the interaction, display question and yes/no question, teacher interruptions, ignore student error, overlap and latch turn, and form focused feedback and construction i.e., extended wait time, student initiated talk, referential question and open ended question, speech modification, direct repair, scaffolding, and content feedback. This result provides critical insights that the implementation of communication in the classroom and also fruitful reflection of other FL (foreign language) teachers to be indigenous people who involve students' contribution actively participate in classroom interaction.
\end{abstract}

Keywords—classroom interaction; teacher talk; construction; obstruction

\section{INTRODUCTION}

Classroom interaction has been recognized as a pivotal tool to enhance students' language skills under the authority of second language teaching and learning. As [1] states that one of central questions in second language acquisition (SLA) concerns is the relationship between interaction and acquisition. Additionally, [2] highlight that interactional competence become the 'fifth skill' because of its major influences on language teaching, testing and material design. Therefore, classroom interaction (further called as 'CI') is critical facet of language teachings which combine many fields.

Formerly in 2002, [3] has analyzed construction and obstruction features of CI in EFL classroom in general, nevertheless this present research attempt to unveil context of EFL in Indonesia. Expert such Nunan who introduce communicative language teaching (CLT) extensively-stated that teachers who are committed to CLT can fail to create opportunities for natural interaction language lesson [4].

Likewise, the analysis of verbal interaction which occurred in language classroom has been led since four last decades by
Sinclair and Coulthard in 1975 identified typical classroom turn taking which so called initiation-respond-feedback (IRF). As [5] stated that in the latter type of classroom interactions, the role of the students as an active participant in social learning began to be emphasized. Because teaching language is different from other subjects-language is not just the medium but also the content [6].

These evidences show that analyzing classroom interaction, whether the researchers or teachers themselvesbecome scintillating tool to enrich language acquisition, language learning, communication skill, and teacher-students engagement to produce genuine interaction inside and outside the classroom. This study established qualitative design to uncover impact of obstruction features excessive than construction. Consequently, it can portray the implementation of communication in language classroom and also benefit for other foreign language teachers in order to create vast opportunity engage students' participation. Optimistically the outcome can remain as supplementary attribution of English teacher training curriculum especially in CI context.

\section{LITERATURE REVIEW}

\section{A. Classroom Interactional Features}

Numerous researches of classroom interaction features have been originated since two last decades, for instance; teacher questions and students feedback [3], teacher questions and their function [4], effect of teacher wait time [5], opportunities for learning which facilitating and hindering potential learning in classroom interaction and conversation analysis [6], and the role of wait time in higher cognitive learning [7]. In fact, CI is focusing in the complex engagement between language, interaction and learning [2]. Therefore, CI very depends on the context where the communication takes place. Different situation, teacher, students, and materials lesson, will result on different interaction content.

Interactional features between teachers and learners are pivotal role in the facilitating or hindering learning opportunities. Research by [6] stated that interactional features identified as promoting interaction were direct error correction (a direct, minimalist approach to correcting errors in order to 
facilitate oral fluency practices); content feedback (feedback on the message rather than its form may promote more genuine communication); checking for confirmation (teachers who do not accept learners' first contribution for maximize learning contribution); extended wait-time (if teachers give learners enough time to answer questions, this will likely lead to an increase in teacher-learner and learner-learner interaction); and scaffolding (teachers must be sensitive enough to know when intervene and provide the missing language, by means of modeling, paraphrasing and prompting). Whilst [2] has been found four features of classroom discourse which prevalent in all parts of the world; control of interaction, speech modification, elicitation and repair. In the following section, the researcher serve classroom interaction features in juxtaposition viewpoint.

\section{B. Obstruction Features of Classroom Interaction}

These following features of classroom interaction are hindering students' potential learning, for instance;

\section{Short wait time}

After asking a question, teachers commonly wait approximately one second or less for students to respond before giving feedback, giving clue, interrupting, giving the right answer, or calling other students to respond. Author [9] asserted that one of these "old habits" is to repeat the question immediately before giving a student time to think. As [8] recommend by his research, teachers should utilize an average wait time of between 3 and 5 seconds if necessary.

\section{Teacher control the interaction}

Teacher control the interaction is exaggerated which can directly apparent from quantity or words, controlling the topic, the content, and procedure of a lesson about what probably the next action, who have turn to participate in conversation and discussion as well as controlling participation in the whole classroom.

\section{Display question \& yes/no question}

Long and Sato in 1983 have been researched a primary classroom level and found a typical type of teacher questions which frequently elicited by ESL teachers are display question and referential question. Expert [2] stated that display question is type of question where teachers already know the answer.

\section{Teacher interruptions}

As we experienced as students in classroom some years ago-surely we have been dealt with teachers' explanation. Teachers mostly take time talking, take students' time to clarify and describe lesson materials. However, actually they were interrupting students' time which ought to be opportunity to speak in target language as well as answer teacher questions.

\section{Ignore student error}

Teachers' role as facilitator and scaffolding in term of teaching and learning-moreover in EFL context, should be maximized. Students' opportunity to speak use target language is in the classroom simultaneously with teachers' guide. As [2] stated that the strategies selected must be related to the pedagogic goals of the moment. A highly controlled practice activity requires more error correction than one where the focus is oral fluency.

\section{Overlap and latch turn}

The most striking feature of the interaction is the overlapping speech (indicated [ ]) within Van Lier's transcription system. Teachers intention to help the learners by correcting errors, it is also clear that over-correction is not very helpful. The flow of the exchange is disrupted to the point that the learner is unable to clearly articulate what she wants to say [2].

\section{Form-focused feedback}

Teachers feedback that focuses on language rather than message. They giving feedback on the words used, not the message [2].

\section{Obstruction Features of Classroom Interaction}

These following features of classroom interaction are facilitating students' potential learning, for instance;

\section{Extended wait time}

Extended wait-time, the time allocated by teachers to let students answer the question. It is not only increases the number of learner responses, it frequently results in more complex answers and leads to an increase in learner/learner interaction. Furthermore, [2] emphasized that when teacher confirms the importance of maintaining harmony between language use and pedagogic aim; the teacher's use of language, consciously or subconsciously, is very much in tune with her specific aim at this stage of the lesson.

\section{Student initiated talk}

In order to pursuit language teaching intention which is able to communicate and interact use target language, English in this case-therefore students have to be more engage in conversation. Teacher should provide opportunity to speak English in classroom through stimulating and facilitating, however, teachers should reduce their control in talk. Teacher should decrease their teacher talk time (TTT) by give space for students to initiating talk in the classroom.

\section{Referential question \& open ended question}

Referential questions are more open ended question, designed to promote discussion and debate, engage learners and produce longer, more complex responses [2]. Referential question and open ended question are type of question which can foster students higher level thinking and critical thinking.

\section{Speech modification}

According to [2], strategies used by teachers to modify their speech for instance; simplified vocabulary and the absence of more idiomatic or regional variations, teachers use discourse markers to assist comprehension and help learners navigate the discourse (discourse marker is such like punctuation in written discourse), teachers clarify and check and confirm meanings such as asking students for clarification and rephrasing students' utterance.

\section{Repair}

Repair simply refers to the ways in which teachers deal with errors. It includes direct and indirect error correction and the ways in which teachers identify errors in the discourse.

\section{Scaffolding}

Study by [7] identify that language breakdowns are likely to occur when learners cannot find the right word or expression in the flow of communication. In order to avoid 
this, teachers feed in the missing language by means of 'scaffolding', or linguistic support provided by the tutor to a learner. The scaffolding is provided to ensure that the learner can manage the task at hand.

7. Content feedback

Expert [2] stated that content feedback, where the focus is on meaning, rather than language form. This is quite rare in many second language classrooms. Most of the feedback from teachers to students is form-focused and deals with languagerelated issues. Feedback on the message rather than its form is also more conducive to genuine communication and is more appropriate in the setting outlined here.

\section{Research Questions}

The research questions are as follow:

- How often obstruction features and construction features of classroom interaction occur in EFL teaching in Indonesia?

- What the implication if the obstruction features excessive than construction features in the context of EFL?

\section{RESEARCH METHODOLOGY}

\section{A. Participants}

The participants were an experienced English teacher with more ten years teaching experience and 32 students of senior high school of a private school in Yogyakarta which involved in three different classroom observation or three times lesson (each lesson approximately 90 minutes).

\section{B. Instruments}

This study used three mutual different form of instruments; observation, transcription from audio form into written form which adapted from Van Lier transcription system and interview as an additional instrument.

\section{Data Analysis}

Qualitative descriptive was used to reveal the features of classroom interaction. Conversation analysis approach to assists interpretation of each extract in juxtaposition of obstruction and construction in classroom interactional features.

\section{RESUlT AND DisCUSSION}

\section{A. Result}

The following table illustrates occurrence features which obstruct and construct the classroom interaction;
TABLE I. FEATURES IN CLASSROOM INTERACTION BASED ON THREE MEETINGS

\begin{tabular}{|c|c|c|c|c|c|c|c|c|c|}
\hline \multicolumn{5}{|c|}{ Obstruction } & \multicolumn{5}{|c|}{ Construction } \\
\hline \multirow[t]{2}{*}{ Features } & \multicolumn{3}{|c|}{ Meeting } & \multirow[t]{2}{*}{ Amount } & \multirow[t]{2}{*}{ Features } & \multicolumn{3}{|c|}{ Meeting } & \multirow[t]{2}{*}{ Amount } \\
\hline & I & II & III & & & I & II & III & \\
\hline $\begin{array}{l}\text { Short wait } \\
\text { time }\end{array}$ & 8 & 16 & 10 & 34 & $\begin{array}{l}\text { Extended } \\
\text { wait time }\end{array}$ & 3 & 4 & 1 & 8 \\
\hline $\begin{array}{l}\text { Teacher } \\
\text { control the } \\
\text { interaction }\end{array}$ & 26 & 28 & 23 & 77 & $\begin{array}{l}\text { Student } \\
\text { initiated talk }\end{array}$ & 1 & 1 & - & 2 \\
\hline $\begin{array}{l}\text { Display } \\
\text { question \& } \\
\text { yes/no } \\
\text { question }\end{array}$ & 44 & 26 & 39 & 109 & $\begin{array}{l}\text { Referential } \\
\text { question \& } \\
\text { open ended } \\
\text { question }\end{array}$ & 4 & 9 & 8 & 21 \\
\hline $\begin{array}{l}\text { Teacher } \\
\text { interruptions }\end{array}$ & 5 & 1 & 3 & 9 & $\begin{array}{l}\text { Speech } \\
\text { modification }\end{array}$ & 6 & 5 & 4 & 15 \\
\hline $\begin{array}{l}\text { Ignore } \\
\text { student error }\end{array}$ & 2 & 4 & - & 6 & Repair & 6 & 4 & 4 & 14 \\
\hline $\begin{array}{l}\text { Overlap and } \\
\text { latch turn }\end{array}$ & 9 & 9 & 9 & 27 & Scaffolding & 2 & 4 & 1 & 7 \\
\hline $\begin{array}{l}\text { Form- } \\
\text { focused } \\
\text { feedback }\end{array}$ & 1 & - & - & 1 & $\begin{array}{l}\text { Content } \\
\text { feedback }\end{array}$ & 4 & - & 1 & 5 \\
\hline
\end{tabular}

a. Numbers above show amount of lines in transcription identify obstruct and construct

Table 1 demonstrated quantity of obstruction excessive the construction of classroom interaction features. High numbers of teachers elicited display question 109 lines, followed by teacher control the interaction identified consisted of 77 lines. On the other hand, the most performed of construction were 21 lines in referential and open ended questions followed by speech modification 15 lines. This indicated that EFL teachers in Indonesia, especially in this research still use high amount of CI features which hindered student learning potential. Exceed of obstruction features in language classroom would hinder students language participation, create ineffective classroom interaction and impeding learning through interaction.

\section{B. Discussion}

From the illustration in result above, found that all features of obstruction and construction appeared in classroom interaction in this research. Exceed of obstruction features in language classroom would hinder students language participation, build ineffective classroom interaction and impeding learning through interaction. Obstruction features of classroom interaction which appeared were short wait time. teacher control the interaction, display question and yes no question, teacher interruptions, ignore student error, overlap and latch turn, and form focused feedback. According to this finding, it was appropriate with previous researches for instance; [8] and [11] which concluded that construction features of classroom interaction can encourage students to engage in classroom discourse and build an effective classroom interaction. Here the researcher deliver some samples of obstruction features in classroom interaction based on three meetings of an English teacher;

1) Obstruct: Short wait time

Extract 1-TD/M1L36

175 T: =the question mark ... kalau diakhiri dengan tanda tanya itu berarti pertanyaan ... ini pertanyaan yang betul-betul pertanyaan atau bukan ... the answering . 
.. jawabannya bagaimana ... the answering? jawabnya? tolong sampaikan kepada dia that the book he ordered has coming . . . baru saja datang ... . kemudian dia menjawabnya bagaimana . . . okay I will tell him ... karena sebetulnya it is not the real question ... bukan pertanyaan yang sebetul-betulnya ... karena pertanyaan untuk memerintah seseorang melakukan sesuatu. . . kalau yang nomer dua bagaimana? kalimat apa? ((2)) (the question mark... if ends by question mark it means interrogative... this is truly question or not ... the answering ... how the answer ... the answering? answer? please tell him that the book he ordered has coming ... recently coming ... then how he answer? okay ... I will tell him ... because actually it is not the real question ... not truly question . . . because the question is to order someone to do something... how about number two? what kind of sentence?)

176 L: perintah (imperative)

177 T: (2) perintah ... ya ... kalimat perintah ... kok tahu kalau kalimat perintah?= (imperative . . ya ... imperative sentence... how do you know that imperative sentence?)

178 L: $\quad=$ soalnya ada $\ldots$ tell him $\ldots=$ (because there $\ldots$ tell him ...)

Extract 1 above demonstrated that short wait time happened when teacher provide only two seconds wait time from sentence to sentence overlapped frequently. Teacher gave overlaid questions toward student with only two seconds of wait time.

\section{2) Obstruct: Teacher control the interaction}

\section{Extract 3-TD/M1L46}

42 T: =salah sambung? ? (wrong connection?) oh ... (standing immediately from his/her chair) do you think it is

\section{LL: no/no/no}

44 T: do you think that the person guess to the caller is the right number?

45 L: right number=

46 T: $\quad=$ right number ... then why ... yaa (1) kenapa salah orang? yaa ... should be something behind ya ... pastinya ada sesuatu dibalik itu ... bagaimana .. apa betul salah sambung? (right number ... then why ... yaa (1) why wrong person? yaa ... should be something behind it ... how ... is it really wrong connected?)

\section{LL: no/no/no}

In this extract 3 , actually teacher has ideal answer in her mind-but then face student's actual answer which inappropriate, the teacher was not agree. Because probably the teacher supposed to only one correct answer. Therefore, students should answer suitable with teacher's expectation.

3) Obstruct: Display question \& yes/no question

\section{Extract 5-TD/M3L109}

104 L: =pembatalan= (cancelling)

105 T: $\quad=$ okay ... pembatalan pesan ... how way you say that in bahasa inggris? (okay ... cancelling message . .. how way you say that in English?)

106 L: =cancel=

107 T: =cancel for? for?

108 L: plan
$\mathrm{T}$ : $\quad=$ a plan $\ldots$ cancelling for a plan $\ldots$ cancelling for a plan ... ((10)) ya ... so that is number one ... (2) so this is the idea ... cancelling a plan . . . cancel ... apa tadi? apa cancel?=

110 L: =membatalkan= (cancelling)

Display question is the most frequently appeared in this research. Line 105, line 107 line 109 were only repeat previous teacher utterances. Probably this is kind of drill regarding students-and this type of question are not encourage to higher order level thinking.

4) Obstruct: Teacher interruptions

\section{Extract 7-TD/M3L67}

$65 \mathrm{~T}: \quad=$ please study well $\ldots$ that is reminding ya $\ldots$ juga suatu peringatan ... kenapa kok harus belajar (= please study well ... that is reminding ya . . . also an attention ... why should learning)

66 L11: biar bisa= (be able)

67 T: $\quad=$ biar bisa . . . bisa apa? bisa menjawab . . . kalau bisa menjawab dalam tes nanti dapat nilai yang bagus ... apakah itu juga disampaikan disini? is there expectation also mentioned in the message? apa harapannya tercantum juga dalam message ini? yaa . . . so there are three ideas ... memang ada tiga ide ya . . . kalimatnya pendek-pendek ... apakah jelas? ya . . . it is not use long sentences ... ternyata kalimatnya juga bukan kalimat yang panjang ... apakah ini menggunakan eee ... banyak kata-kata di dalam kalimatnya? do we find that there are many sentences (be able ... able what? able to answer... if able to answer in test later get good score ... is it also conveyed here? is there expectation also mentioned in the message? is there expectation in this message? yaa ... so there are three ideas ... there are three ideas ya ... short sentences ... is it clear? ya ... it is not use long sentences . . . in fact the sentence isn't long sentence ... is this use eee . . . too many words in the sentence? do we find that there are many sentences)

68 LL: $n o / n o / n o=$

When student answer in line 66, but the teacher immediately interrupt in line 67, therefore students miss opportunity to answer. Student's chance to answer is used by teacher to re-explain previous question.

5) Obstruct: Ignore student error

\section{Extract 9-TD/M1L104}

102 T: =yang nelfon? yang nelfon siapa? (who's calling? who's calling?)

103 L8: ((2)) repair

104 T: $\quad$ yaa ... from the service center ... yaa ... from the computer service center . . . telling that ... memberitahukan kalau . . . bu ternyata komputernya tambah rusak ... apakah betul begitu? is it so? oya? komputernya tambah rusak setelah dibawa ke service? (yaa ... from the service center . . yaa ... from the computer service center ... telling that ... telling that ... miss actually the computer is more damage ... is it true? is it so? the computer is more damage after took to service)

In line 108 when student answer teacher's question, and teacher neglected what student conveyed.

6) Obstruct: Overlap and latch turn 
106 T:

=ya $\ldots$ now we begin with number one $\ldots$ kita bahas mulai dari nomer satu (choosing one of student to read his/her answer) (inaudible) ... the profession? (ya ... now we begin with number one ... we begin to discuss from number one ... the profession?)

107 L: doctor=

108 T: $\quad=$ a doctor $\ldots$ so $\ldots$ a call from a doctor to tell that .. . siapa ... siapa yang dituju? who is the caller want to talk? what is the caller want to talk about? remind to . . jangan lupa untuk minum obat atau kontrol? ( $=a$ doctor ... so ... a call from a doctor to tell that ... who ... who is refer to? who is the caller want to to? what is the caller want to talk about? remind to ... don't forget to drink the drugs or control?)

109 L: $=$ control=

Extract 11 above show how overlap between one sentence and following sentence. Moreover, in line 107 when student answer, teacher immediately reply -in latch turn at line 108. Whereas probably the student still want to continue his/her sentence.

\section{7) Obstruct: Form-focused feedback}

\section{Extract 13-TD/M1L54}

52 T: tidak ada disini ... ya ... di tempat... so ... what is the person way ... dia terus ngapain itu?= (there is no here ... ya ... in the place.... what is the person way ... then what he do?)

53 L: =ngasih pesan= (giving message)

54 T: $=$ memberi pesan .. MENINGGALKAN PESAN ... what is meninggalkan pesan in bahasa inggris? to ... to? meninggalkan pesan? (giving message ...

LEAVING MESSAGE . . . what is leave a message in English? to ... to? leave a message?)

In extract 13 teacher focused on form feedback. If this condition continued frequently, probably students face frightened situation and won't be able to engage in conversation or interaction. Whereas in CI is not prioritize in accuracy, but emphasized on fluency - even confluency.

\section{CONCLUSION}

Actually, classroom interaction is a complex object to being studied. Each classroom might have different foreign language teacher who also conveying different classroom language. Especially for second language or foreign language teachers, according to the previous discussion-it is important to let students talk, it was rather than controlling entire classroom language. Teachers were modeling English dialect in the classroom, scaffolding through one of tools, and engage effective classroom interaction features. If classroom interaction implemented properly refer to classroom context, students will be able to participate and contribute within interaction. Not every construction features can implemented in very classroom. Different context has different classroom interaction features. For instance, students who face foreign language for the first time, teachers should provide low level questions, display question, and more form focused feedback. Teachers sometime unconscious that what they were doing hinder potential learning of students. Consequently, this study suggests that features of classroom interaction can be implemented to being taught in foreign language teacher training. Correspondingly, result of this research provides critical insights that the implementation of classroom interaction can be fruitful reflection of other FL (foreign language) teachers to be indigenous people who involve students' contribution actively participate in classroom interaction.

\section{REFERENCES}

[1] R. Ellis, Second Language Acquisition and Language Pedagogy. Multilingual Matters, 1992.

[2] S. Walsh, Exploring Classroom Discourse (Language in Action). London: Routledge, 2011.

[3] M. Coulthard, "Approaches to the Analysis of Classroom Interaction," Education. Rev., vol. 26, no. 3, pp. 229-240, 1974.

[4] A. Dekker-Groen, M. van der Scaaf, and K. Stokking, "Teachers' Questions and Responses during Teacher-Student Feedback Dialogues,” Scandinav. J. of Education. Res., vol. 59, no. 2, pp. 231254.

[5] B. Inan and D. Fidan, "Teacher Questions and Their Functions in Turkish as a Foreign Language (TFL) classes,” Procedia - Soc. and Behavior. Sci., vol. 70, pp. 1070-1077, 2013.

[6] V. Cook, Second Language Learning and Second Language Teaching. London: Hodder Education, 2008.

[7] K. Tobin, "Effects of Teacher Wait Time on Discourse Characteristics in Mathematics and Language Arts Classes,” American Education. Res. J., no. 2, pp. 191-200, 1986.

[8] M. Cancino, "Assesing Learning Opportunities on EFL Classroom Inetraction: What Can Conversation Analysis Tell Us?” RELC Journal, pp. 1-15, 2015.

[9] D. Kauchak and P. D. Eggen, Learning and Teaching (Research Based Methods). Massachusetts, Allyn and Bacon, 1989.

[10] K. Tobin, "The Role of Wait Time in Higher Cognitive Level Learning,” J. Rev. of Education. Res., vol. 57, no. 1, pp. 69-95, Spring 1987.

[11] S. Walsh, "Construction or obstruction: teacher talk and learner involvement in the EFL classroom,” Lang. Teaching Res., vol. 6, no. 1, pp. 3-23, 2002.

[12] A. Kawalkar and J. Vijapurkar, "Scaffolding Science Talk: The role of teachers' questions in the inquiry classroom," Int. J. of Sci. Edu., vol. 35, no. 12, pp. 2004-2027, 2013. 